\section{OPEN ACCESS}

Edited by: Michelle Meyer,

University of North Carolina at Chapel Hill, United States

Reviewed by: Khanh-Van Tran,

UMass Memorial Medical Center,

United States

Timothy P. Fitzgibbons,

University of Massachusetts Medical

School, United States

*Correspondence:

Leonardo Roever

leonardoroever@hotmail.com

Specialty section:

This article was submitted to

Atherosclerosis and Vascular

Medicine,

a section of the journal

Frontiers in Cardiovascular Medicine

Received: 25 January 2021 Accepted: 17 March 2021

Published: 21 April 2021

Citation:

Rosa MI, Grande AJ, Lima LD,

Dondossola ER, Uggioni MLR,

Hernandez AV, Tse G, LiU T,

Pontes-Neto OM, Biondi-Zoccai G, Neto MG, Durães AR, Sá MPBO,

Resende ES and Roever L (2021)

Association Between Epicardial

Adipose Tissue and Stroke.

Front. Cardiovasc. Med. 8:658445.

doi: 10.3389/fcvm.2021.658445

\title{
Association Between Epicardial Adipose Tissue and Stroke
}

\begin{abstract}
Maria Inês Rosa ${ }^{1}$, Antonio José Grande ${ }^{2}$, Leticia Dorsa Lima ${ }^{2}$, Eduardo Ronconi Dondossola ${ }^{1}$, Maria Laura Rodrigues Uggioni ${ }^{1}$, Adrian V. Hernandez ${ }^{3,4}$, Gary Tse ${ }^{5}$, Tong Liu ${ }^{6}$, Octávio Marques Pontes-Neto ${ }^{7}$, Giuseppe Biondi-Zoccai ${ }^{8}$, Mansueto Gomes Neto ${ }^{9,10,11,12}$, André Rodrigues Durães ${ }^{10}$, Michel Pompeu B. O. Sá ${ }^{13,14,15}$, Elmiro Santos Resende ${ }^{16,17}$ and Leonardo Roever ${ }^{17 *}$

${ }^{1}$ Laboratory of Biomedicine Translational, University of Extremo Sul Catarinense, Criciúma, Brazil, ${ }^{2}$ Department of Medicine, State University of Mato Grosso Do Sul, Mato Grosso, Brazil, ${ }^{3}$ Hartford Hospital Evidence-Based Practice Center, University of Connecticut, Hartford, CT, United States, ${ }^{4}$ Vicerrectorado de Investigacion, Universidad San Ignacio de Loyola, Lima, Peru, ${ }^{5}$ Xiamen Cardiovascular Hospital, Hong Kong, China, ${ }^{6}$ Tianjin Key Laboratory of lonic-Molecular Function of Cardiovascular Disease, Department of Cardiology, Tianjin Institute of Cardiology, the Second Hospital of Tianjin Medical University, Tianjin, China, ${ }^{7}$ Stroke Service, Neurology Division, Ribeirão Preto Medical School, University of São Paulo, Ribeirão Preto, Brazil, ${ }^{8}$ Department of Medico-Surgical Sciences and Biotechnologies, Sapienza University of Rome, Latina, Italy, ${ }^{9}$ Mediterranea Cardiocentro, Naples, Italy, ${ }^{10}$ Physical Therapy Department, Federal University of Bahia-Universidade Federal Da Bahia, Salvador, Brazil, ${ }^{11}$ Programa de Pós-Graduação em Medicina e Saúde-Universidade Federal Da Bahia, Salvador, Brazil, ${ }^{12}$ Physiotherapy Research Group, UFBA, Salvador, Brazil, ${ }^{13}$ The GREAT Group, Salvador, Brazil, ${ }^{14}$ Division of Cardiovascular Surgery of Pronto Socorro Cardiológico de Pernambuco-PROCAPE, Recife, Brazil, ${ }^{15}$ Department of Surgery, University of Pernambuco-Universidade de Pernambuco, Recife, Brazil, ${ }^{16}$ Nucleus of Postgraduate and Research in Health Sciences of Faculty of Medical Sciences and Biological Sciences Institute-FCM/ICB, Recife, Brazil, ${ }^{17}$ Department of Clinical Research, Federal University of Uberlândia, Uberlândia, Brazil
\end{abstract}

Epicardial adipose tissue (EAT) is correlated with endothelial dysfunction, metabolic syndrome, increased mortality and recent studies showed a possible association with the increased risk of stroke. We performed a systematic review of studies evaluating the association between EAT and stroke. Eighty studies met the inclusion criteria and were consequently analyzed. The review had Five main findings. First, the increased epicardial fat thickness (EFT) may be associated with the stroke episode. Second, regardless of the imaging method (echocardiography, MRI, and CT) this association remains. Third, the association of metabolic syndrome and atrial fibrillation seems to increase the risk of stroke. Fourth, this systematic review was considered as low risk of bias. Despite being unable to establish a clear association between EAT and stroke, we have organized and assessed all the research papers on this topic, analyzing their limitations, suggesting improvements in future pieces of research and pointing out gaps in the literature. Furthermore, the mechanistic links between increased EAT and stroke incidence remains unclear, thus, further research is warranted.

Keywords: stroke, epicardial adipose tissue, systematic review, atherosclerosis, metabolic syndrome

\section{INTRODUCTION}

Epicardial adipose tissue (EAT) is more prominent on the right side of the heart on the side wall of the right ventricle and is located between the pericardium and the myocardium $(1,2)$. It acts not only as anatomical fat deposit, but also as a biologically active tissue that secretes hormones, pro-inflammatory cytokines and proteins $(3,4)$. The EAT can be determined by imaging tests, such as Computed tomography (CT), Echocardiography (EC) and Magnetic Resonance Imaging (MRI) (5-7). 
Determinant factors for increasing EAT are: unbalanced diet, obesity, age ethnicity, gender, low socioeconomic and cultural level, stress and sedentary lifestyle (8-10).Studies have shown that EAT is associated with insulin resistance, diabetes, hypertension, dyslipidemia, atrial fibrillation, increased risk of cardiovascular disease and stroke, the latter being the focus of this study (11-14).

Stroke falls into the category of cerebrovascular diseases that affects the individual due to the change of blood flow to the brain. It is characterized by the acute onset of a neurological deficit, being understood by the rapid occurrence of clinical signs, resulting from focal or global disturbances of brain function, resulting in symptoms lasting longer than $24 \mathrm{~h}(15,16)$.

Findings from the Global Burden of Disease Study (2010) (15) show that the incidence of stroke due to ischemia is $68 \%$, whereas the incidence of hemorrhagic stroke is $32 \%$. A percentage of $87 \%$ of strokes due to ischemia, 10 of intracerebral hemorrhage and 3 of subarachnoid hemorrhage were observed, respectively, in the United States (17). According to the World Health Organization $(2018)(18,19)$, ischemic heart disease and stroke are the largest cause of death in the world, accounting for 15.2 million deaths in 2016. Stroke is the main cause of death in most of Latin American countries, and Brazil has the highest stroke mortality rate in the Americas. The highest incidence occurs after 65 years; however, it is observed occurring earlier in the population (16, 20-22).

Stroke stands out as an important focus of discussion in Public Health with regard to Chronic Non-communicable Diseases, placing a large socioeconomic burden on patients (23). Taking into account that stroke is among the diseases that most affect individuals in various age groups and both sexes worldwide, and that EAT has raised questions about the associated risks, this is the first systematic review and meta-analysis that explores the association of these two factors. In addition, the methods used in systematic reviews seek to minimize biases and improve the reliability and accuracy of conclusions.

\section{METHODS}

We performed a systematic review according to a protocol using PRISMA-statement guidelines (24). The review protocol was registered at PROSPERO (registration number: CRD42018091399).

\section{Search Strategy}

A search strategy was developed using the following terms: "epicardial fat", OR "epicardial adipose tissue" and "ischemic stroke" OR "brain ischaemia" OR "stroke" as text words and Medical Subject Headings (i.e., MeSH and EMTREE) and searched MEDLINE, EMBASE, Scopus, Cochrane Central Register of Controlled Trials (CENTRAL), Biomed Central, Web of Science, IBECS, LILACS, Congress Abstracts, and Grey literature (Google Scholar and the British Library) for studies

\footnotetext{
Abbreviations: EAT, epicardial adipose tissue; EFT, epicardial fat thickness, CT, computed tomography, EC, echocardiography; MRI, magnetic resonance imaging, AF, atrial fibrillation; BMI, body mass index, ESUS, embolic stroke of undetermined source; AIS, acute ischemic stroke; NIHSS, National Institute of Health Stroke Scale.
}

published from January 1990 to May 2020. The study was only about articles on human beings and all languages. Reference lists of all available primary studies were reviewed to identify additional relevant citations.

\section{PECO Strategy}

This review included observational studies due to its characteristics of associating a factor and a condition, the construction of the research question was done through the acronym PECO (25) where each letter represents a component of the issue and is presented below:

Population: Individuals of either sexes with 18 years or more;

Exposure and Control: Epicardial adipose tissue measured by Echocardiogram or tomography or MRI.

O: Stroke diagnosed by a physician using CT or MRI.

\section{Screening of Abstracts for Eligibility}

Two reviewers (M.I.R and A.J.G) independently screened the titles and abstracts. The screening process was conducted in Covidence (http://covidence.org). The potentially relevant full texts were read in full, and those that met the inclusion criteria were included in this review. Data from all included studies were also extracted independently by two reviewers and when there was some divergence, a third reviewer resolved the conflict.

\section{Study Selection}

This review included cohort studies (prospective or retrospective), case-control, and cross-sectional studies evaluating the association of epicardial fat and stroke.

\section{Inclusion Criteria}

Studies with participants of both sexes with 18 years or more;

Populations of patients admitted with stroke.

\section{Exclusion Criteria for Studies}

We excluded preclinical studies, and studies that evaluated the association with other types of fat.

\section{Data Extraction}

Two reviewers (M.I.R and A.J.G) independently extracted data from the primary studies included in the study. Final decision for inclusion or exclusion of studies in this systematic review was made with reference to the study project registered at PROSPERO. Disagreements about the inclusion or exclusion of the study were resolved by consensus. In the data extraction form we evaluate the data on the characteristics of the patients, methods used, and the outcomes of each study.

\section{Assessment of Methodological Quality}

The quality analysis of the studies was performed by two investigators (E.R.D and M.I.R) independently using the Downs and Black (26) instruments for the case-control and cohort studies and the JBI Critical Appraisal Checklist (27) for crosssectional studies. Any discrepancies in the evaluation of the quality of studies among researchers were resolved by discussion and consensus among all authors. 


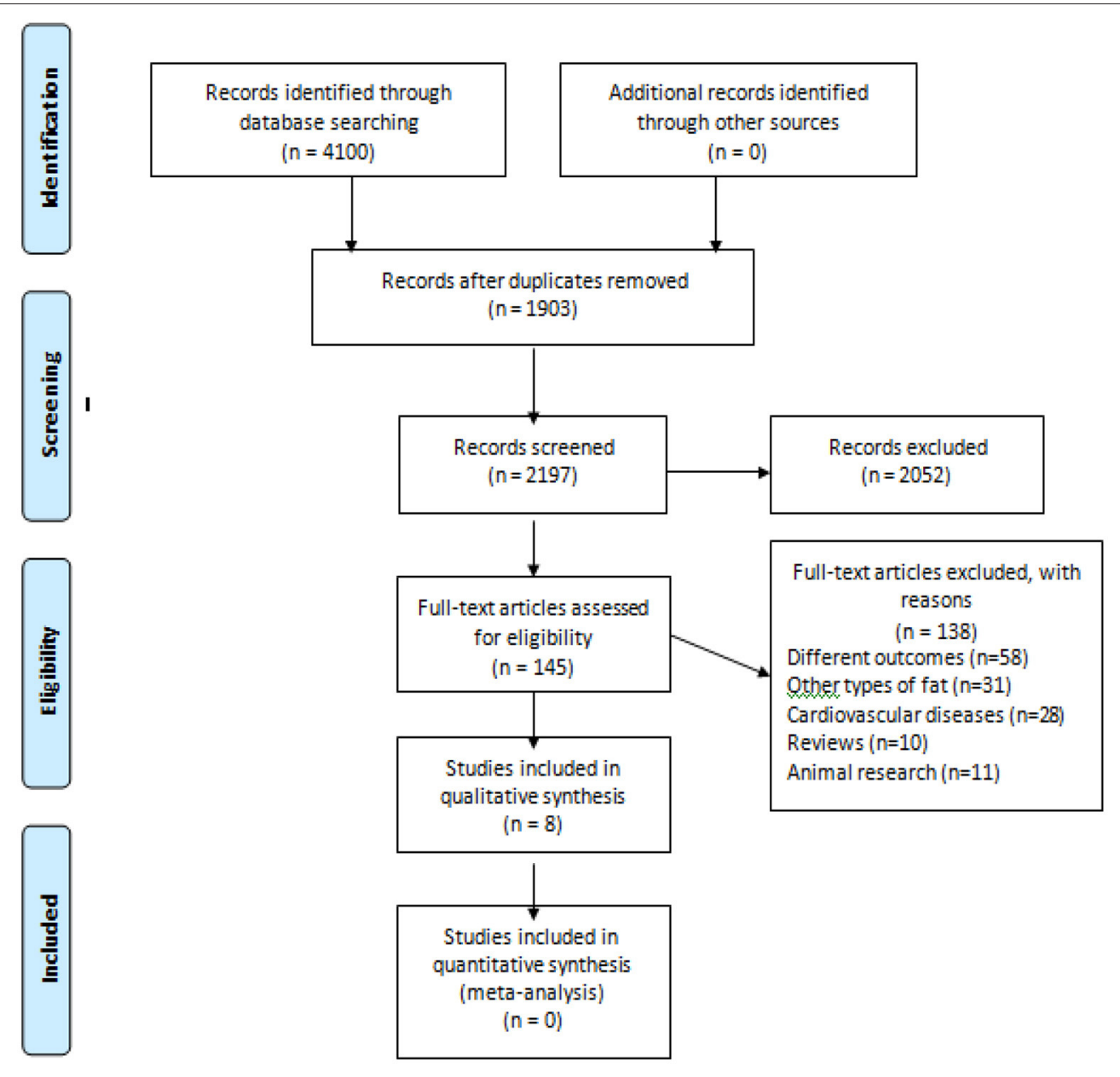

FIGURE 1 | Flowchart.

\section{Data Synthesis and Statistical Analysis}

The results were described in tables individually; no metaanalysis could be conducted due to substantial heterogeneity of data.

\section{RESULTS}

In the initial search we found 2,197 studies, of which 2,052 were removed after evaluations of titles and abstracts. A total of 145 studies were read in full. From these, 139 studies were excluded because they did not meet the criteria, thus, 8 studies were included Gürdal et al. (cross-sectional) (19), Akil et al. (cross-sectional) (28); Altun et al. (case-control) (29); Chu et al. (prospective cohort) (30); Tsao et al. (cross-sectional) (13); Cho et al. (retrospective cohort) (14); Tsao et al. (case-control) (31) and Cosansu and Yilmaz (cross-sectional) (32). The flowchart of the study selection is shown in Figure 1.

These included studies were from countries such as Taiwan (three studies), Turkey (three studies) and Korea (one study). Referring to the sample characterization, the total was 893 individuals with 360 in the control group and 747 in the case group. The elderly population was the most prevalent in the studies (both in the control groups and in the case groups). The age ranges were 50 and 73 years, being the majority composed of females. The characteristics of the included studies are in Table $\mathbf{1 .}$

Akil et al. (28) gathered population of 85 individuals, 38 patients belonging to the case group, a BMI of $25.1 \pm 1.3$ $\mathrm{kg} / \mathrm{m}^{2}$, and 47 patients in the control group, with a BMI of 24.9 $\pm 4.7 \mathrm{~kg} / \mathrm{m}^{2}$. The cut-off point established by the author for epicardial fat in order to demonstrate risk was $5.35 \mathrm{~mm}$, with a sensitivity of 73.7 and $83.6 \%$ of specificity, and the ROC curve (95\% CI) provided a value of $0.802(0.699-0.905)-p>0.001$. The validation of the patients with ischemic stroke was given by Magnetic Resonance and Computed Tomography. The findings demonstrate a significant increase in epicardial adipose tissue $(5.95 \pm 1.14 \mathrm{~mm})$ in patients with ischemic stroke compared to patients in the control group (without ischemic stroke) (4.86 \pm $0.68 \mathrm{~mm})-p<0.001$.

Altun et al. (29) gathered a sample of 143 patients, in which the case group the $\mathrm{n}$ was 61 with a mean age of $71.4 \pm 11$ years, $56 \%$ female with a waist size evaluated at $100.8 \mathrm{~cm}$. In the control group, the $\mathrm{n}$ was 82 with a mean age of $68.6 \pm 8$ years, where 
TABLE 1 | Characteristics of primary studies.

\begin{tabular}{|c|c|c|c|c|c|c|c|c|c|c|}
\hline Author/year & Country & Design & $\begin{array}{l}\text { Mean age } \\
\text { case/control }\end{array}$ & $\mathrm{N}$ cases $(\mathrm{F} / \mathrm{M})$ & $\mathrm{N}$ controls $(\mathrm{F} / \mathrm{M})$ & $\begin{array}{l}\text { Definition of EAT } \\
\text { and measurement }\end{array}$ & Measurement for stroke & $\begin{array}{c}\text { Size } \\
\text { EAT(cases) }\end{array}$ & $\begin{array}{c}\text { Size } \\
\text { EAT(controls) }\end{array}$ & $\begin{array}{l}\text { Measure of } \\
\text { association }\end{array}$ \\
\hline Altun et al. (29) & Turkey & Case-control & $\begin{array}{c}71.4 \pm \\
11 / 68.6 \pm 8\end{array}$ & $61(34 / 27)$ & $82(40 / 42)$ & $\begin{array}{l}\text { Found between the } \\
\text { heart and } \\
\text { pericardium/ } \\
\text { Echocardiography }\end{array}$ & Clinical signs in the last $24 \mathrm{~h}$ & $\begin{array}{c}4,8 \pm \\
0,9 \mathrm{~mm}\end{array}$ & $3,8 \pm 0,7 \mathrm{~mm}$ & $\begin{array}{c}\text { OR } 3.178 \\
\text { (95\%Cl- } \\
1.404-7.195) .\end{array}$ \\
\hline Akil et al. (28) & Turkey & $\begin{array}{l}\text { Cross } \\
\text { sectional }\end{array}$ & $\begin{array}{c}50.5 \pm \\
13.9 / 53.7 \pm \\
9.0\end{array}$ & $38(15 / 23)$ & $47(20 / 27)$ & $\begin{array}{l}\text { Space between the } \\
\text { pericardial layers/ } \\
\text { Echocardiography }\end{array}$ & $\begin{array}{l}\text { Computed Tomography and } \\
\text { magnetic resonance imaging }\end{array}$ & $6,0 \pm 1 \mathrm{~mm}$ & $4,4 \pm 0,9 \mathrm{~mm}$ & $\begin{array}{c}\text { OR } 10.436 \\
(95 \% \mathrm{Cl}- \\
3.032-35.570) .\end{array}$ \\
\hline Chu et al. (30) & Taiwan & $\begin{array}{l}\text { Prospective } \\
\text { cohort }\end{array}$ & $\begin{array}{c}68 \pm 10 / 73 \pm \\
10\end{array}$ & $93(30 / 63)$ & $97(32 / 65)$ & $\begin{array}{c}\text { Space located } \\
\text { between the visceral } \\
\text { pericardium and the } \\
\text { external wall of the } \\
\text { myocardium/ } \\
\text { Echocardiography }\end{array}$ & Clinical signs & $\begin{array}{c}8,1 \pm \\
1,6 \mathrm{~mm}\end{array}$ & $4.4 \pm 0.9 \mathrm{~mm}$ & $\begin{array}{c}\text { HR univariable } \\
1.286(95 \% \mathrm{Cl}- \\
1.168-1.417) . \\
\mathrm{HR} \\
\text { multivariable } \\
1.211(95 \% \mathrm{Cl}- \\
1.084-1.351) .\end{array}$ \\
\hline Tsao et al. (13) & Taiwan & $\begin{array}{l}\text { Cross } \\
\text { sectional }\end{array}$ & $\begin{array}{c}64.11 \pm \\
11.43 / 63.25 \pm \\
7.56\end{array}$ & $\begin{array}{c}27(8 / 21) \\
\text { Patients with } \\
\text { atrial fibrillation }\end{array}$ & $20(5 / 15)$ & $\begin{array}{l}\text { Fat located between } \\
\text { the visceral } \\
\text { pericardium and the } \\
\text { myocardium / } \\
\text { Computed } \\
\text { Tomography }\end{array}$ & Clinical signs & $\begin{array}{c}53,07 \pm \\
14.67 \mathrm{~cm}^{3}\end{array}$ & $\begin{array}{c}21.46 \pm \\
14.64 \mathrm{~cm}^{3}\end{array}$ & $\begin{array}{c}\text { Univariable OR } \\
1,15 \text { (95\% } \\
\text { Cl-1,09-1,21). } \\
\text { Multivariable } \\
1,12(95 \% \mathrm{Cl}- \\
1,06-1,19) .\end{array}$ \\
\hline Cho et al. (14) & Korea & $\begin{array}{l}\text { Retrospective } \\
\text { Cohort }\end{array}$ & $\begin{array}{c}65.4 \pm \\
12.1 / 75.0 \pm \\
10.6\end{array}$ & $\begin{array}{c}\text { Ischemic stroke } \\
\text { without AF: } 179 \\
(65 / 114) \\
\text { ischemic stroke } \\
\text { with AF: } \\
35(20 / 15)\end{array}$ & $\begin{array}{l}\text { There was no } \\
\text { control }\end{array}$ & $\begin{array}{l}\text { Epicardial fat was } \\
\text { defined as the } \\
\text { echo-free space } \\
\text { between the Outer } \\
\text { wall of the } \\
\text { myocardium and the } \\
\text { visceral layer of t e } \\
\text { pericardium. } \\
\text { Echocardiography }\end{array}$ & Magnetic resonance imaging & $\begin{array}{l}6.5 \pm \\
1.2 \mathrm{~mm}\end{array}$ & $5.3 \pm 1.2 \mathrm{~mm}$ & Uninformed. \\
\hline Tsao et al. (31) & Taiwan & Case-control & uninformed & $\begin{array}{l}20 \text { Patients with } \\
\text { atrial fibrillation }\end{array}$ & 34 & $\begin{array}{l}\text { uninformed/Computed } \\
\text { Tomography }\end{array}$ & uninformed & $\begin{array}{c}60.27 \pm \\
13.10 \mathrm{~cm}^{3}\end{array}$ & $\begin{array}{c}24.34 \pm 6.78 \\
\mathrm{~cm}^{3}\end{array}$ & Uninformed. \\
\hline $\begin{array}{l}\text { Gürdal et al. } \\
\text { (19) }\end{array}$ & Turkey & Case-control & $43 \pm 8 / 38 \pm 7$ & $40(16 / 24)$ & $37(20 / 17)$ & $\begin{array}{l}\text { Epicardial adipose } \\
\text { tissue (EAT), is a } \\
\text { visceral fat depot of } \\
\text { the heart, is located } \\
\text { on the surface of the } \\
\text { heart between the } \\
\text { myocardium and } \\
\text { visceral pericardium/ } \\
\text { Echocardiographic }\end{array}$ & $\begin{array}{l}\text { ESUS was defined according to } \\
\text { the criteria proposed by the } \\
\text { Cryptogenic Stroke/ESUS } \\
\text { International Working Group as } \\
\text { a visualized nonlacunar brain } \\
\text { infarct in the absence of the } \\
\text { following causes: extracranial or } \\
\text { intracranial atherosclerosis } \\
\text { causing } \geq 50 \% \text { luminal stenosis } \\
\text { in arteries supplying the area of } \\
\text { ischemia; major cardioembolic } \\
\text { sources; and any other specific } \\
\text { cause of stroke (eg, vasculitis, } \\
\text { dissection, } \\
\text { migraine/vasospasm, drug } \\
\text { misuse)./MRI }\end{array}$ & $\begin{array}{c}5.51 \pm \\
0.82 \mathrm{~mm}\end{array}$ & $3.96 \pm 0.51$ & Uninformed \\
\hline
\end{tabular}




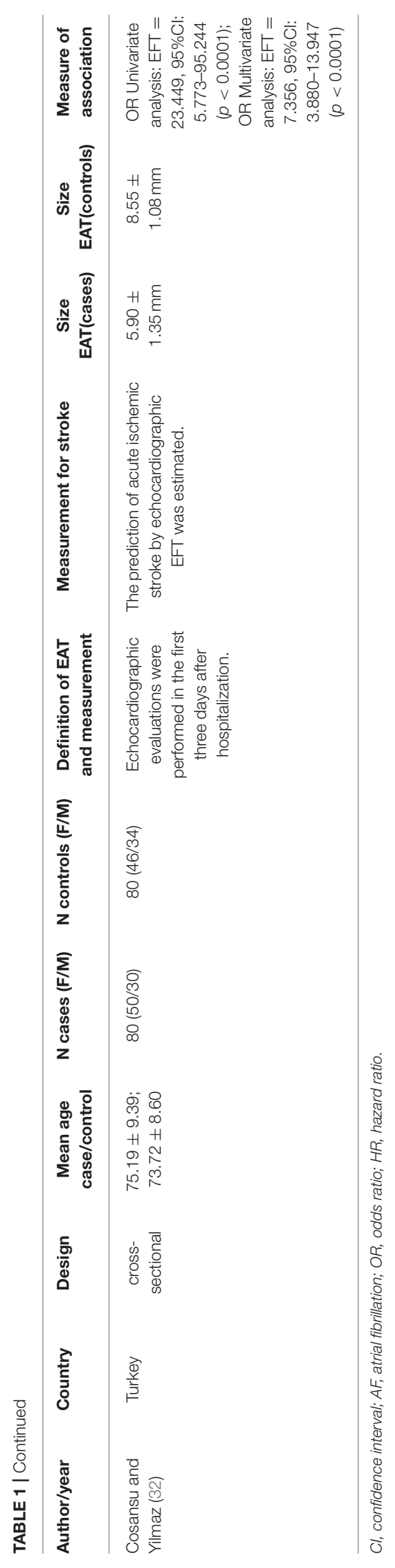

the male predominated (51\%), with a waist circumference of $100.7 \mathrm{~cm}$. The method used to determine the epicardial adipose tissue was also through echocardiography. The determination of the ischemic stroke was defined by the clinical signs of focal disturbance of the cerebral function, of probable ischemic origin, with duration of more than $24 \mathrm{~h}$. However, a cranial computed tomography scan was performed in $100 \%$ of patients and an MRI in $84 \%$ of the patients and the National Institute of Health Stroke Scale (NIHSS) score was also used to assess the severity of stroke. With a cutoff point of $4.28 \mathrm{~mm}$ for epicardial adipose tissue [ROC curve $=0.84(95 \%$ CI $0.772-0.908)]$, indicating a sensitivity of $81 \%$ and specificity of $81 \%(p=<0.001)$, the correlation of epicardial adipose tissue and ischemic stroke showed that in the case group it was higher $(4.8 \pm 0.9 \mathrm{~mm})$ than in the control group $(3.8 \pm 0.7 \mathrm{~mm})-p<0.001$.

Tsao et al. (13) studied 115 patients divided into three groups: a group (case) with 27 patients with atrial fibrillation (AF) and stroke [Body mass índex (BMI) of $23.89 \mathrm{~kg} / \mathrm{m}^{2} \pm 3.51$ ], another group consisted of 68 with atrial fibrillation, but no stroke and one last group (control) with 20 patients without atrial fibrillation and without stroke (BMI of $24.97 \mathrm{~kg} / \mathrm{m}^{2} \pm 3.14$ ). The method used to detect stroke was through clinical signs and the measurement of epicardial adipose tissue was performed by means of a Computed Tomography scan with a cutoff point of $40.68 \mathrm{~cm}^{3}$, where the result given to the case group (stroke $+\mathrm{AF}$ ) was $53.07 \pm 14.67 \mathrm{~cm}^{3}$ and for the control group (without AF and without stroke) was $21.46 \pm 14.64 \mathrm{~cm}^{3}(p<0.001)$. However, the group with AF without stroke had a score of $29.85 \mathrm{~cm}^{3}$ in its epicardial adipose tissue value. In relation to additional biochemical tests, Tsao et al. (13) presented LDL values of 103.85 $\pm 25.06 \mathrm{mg} / \mathrm{dl}$ for the case group and $105.17 \pm 19.94 \mathrm{mg} / \mathrm{dl}$ for the control group.

The study by Tsao et al. (31) included three groups with individuals who had atrial fibrillation and had the epicardial adipose tissue measured in the left atrium. Although it was not possible to obtain the article completely, its published abstract provided enough data for it to be included in this review. The sample consisted of 122 individuals, 34 in the control group (group 1), 68 patients in the group with $\mathrm{AF}$ and no history of stroke (group 2) and 20 patients in the group with stroke and AF (group 3). The epicardial adipose tissue measurement was performed by computed tomography and the control group obtained a value of $24.34 \pm 6.78 \mathrm{~cm}^{3}$ in relation to the group with stroke and AF that reached a value of $60.27 \pm 13.10 \mathrm{~cm}^{3}$. The value of group 2 (patients with $\mathrm{AF}$ and without stroke) obtained a value of $32.11 \pm 11.87(p>0.001)$.

Chu et al. (30) obtained 32 women and 65 men in the control group, being the BMI $26.8 \pm 4.3 \mathrm{~kg} / \mathrm{m}^{2}$. In the experimental group, 30 women and $63 \mathrm{men}$, with a BMI of $25.6 \pm 3.9 \mathrm{~kg} / \mathrm{m}^{2}$, totaled a $\mathrm{n}$ of 190 .This study through a ROC curve found that the best value between EAT and prediction of cardiovascular disease events is $6.0 \mathrm{~mm}$, where the value $\leq 6.0 \mathrm{~mm}$ was attributed to the control population and a value $\geq 6.0 \mathrm{~mm}$ for the case group. Therefore, the control group, when submitted to Echocardiography to measure the epicardial adipose tissue, obtained a value of $4.4 \pm 0.9 \mathrm{~mm}$ when compared to the group that had a finding of $8.1 \pm 1.6 \mathrm{~mm}(p<0.001)$. 
Gürdal et al. (19) investigated the measurement of echocardiographic EAT in young patients with embolic stroke of undetermined source (ESUS) Patients with ESUS had a significantly higher EFT than the control group $(5.51 \pm 0.82$ vs. $3.96 \pm 0.51 ; P<0.01)$. In addition, there was a positive correlation between EFT and serum C-reactive protein levels $(r$ $=0.284 ; P<0.05)$. As an ideal cutoff, a high-risk EFT value of $4.6 \mathrm{~mm}$ was determined to predict ESUS, with a sensitivity of $87.5 \%$ and a specificity of $81.1 \%$. EAT was significantly higher in young patients with ESUS than in healthy subjects.

Cho et al. (14) obtained a population composed of 214 patients diagnosed with ischemic stroke by magnetic resonance imaging, whose mean age was $66.8 \pm 12.3$ years and $39.7 \%$ of the sample was represented by women. The study population was divided into two groups, a group that had ischemic stroke $+\mathrm{AF}(n=$ 35) (BMI of $24.3 \pm 3.3 \mathrm{~kg} / \mathrm{m}^{2}$ ) and one group with ischemic stroke without $\left.\operatorname{AF}(n=179) 3.2 \mathrm{~kg} / \mathrm{m}^{2}\right)$. The determination of the EAT was performed by means of an Echocardiography, which showed that the case group (with ischemic stroke $+\mathrm{AF}$ ) presented values of $6.5 \pm 1.2 \mathrm{~mm}$ vs. $5.3 \pm 1.2 \mathrm{~mm}$ of the ischemic stroke group without AF (control group), $(p<0.001)$. Additional examinations included dyslipidemia in $31.3 \%$ of the population with (AF without stroke) and $22.9 \%$ in the population with AF).

Cosansu and Yilmaz (32) included 80 AF patients with acute ischemic stroke (AIS) and $80 \mathrm{AF}$ controls with the same age and sex without AIS, in this study it was observed that compared to the control group, patients with AF with AIS had significantly greater epicardial thickness $(8.55 \pm 1.08$ vs. $5.90 \pm 1.35 \mathrm{~mm}$; $P<0.0001)$, and in multivariate regression analysis indicated that EFT independently predicts AIS in patients with AF.

\section{Risk of Bias of the Included Studies}

Using the Downs and Black tool, methodological evaluation showed an average of 20 points, being the methodological quality of the studies considered good, described in Table 2.

The JBI Critical Appraisal Checklist, although not providing a score at the end of the evaluation, also resulted in a good methodological quality of the post-evaluation studies shown in Table 3. After analyzing the quality of the studies, this systematic review was considered as low risk of bias.

\section{DISCUSSION}

This review included eight studies in which it can observed an association between EAT and stroke involvement. Studies showed an association of increased thickness of epicardial fat measured by methods such as echocardiography, MRI, and CT with stroke diagnosed by clinical examination, MRI, or CT. Different methods of quantifying epicardial fat suggest that its increased thickness is associated with an increased risk of the patient having a stroke. Obesity and central adiposity are associated with the increase in risk factors for atherosclerosis and fibrillation and, consequently, with a greater incidence of stroke in this population. Ischemic stroke in the studies had a greater relationship between the increase in epicardial fat, central adiposity and risk factors. The percentage of dyslipidemia was higher in the stroke group. In patients with high volume and/or

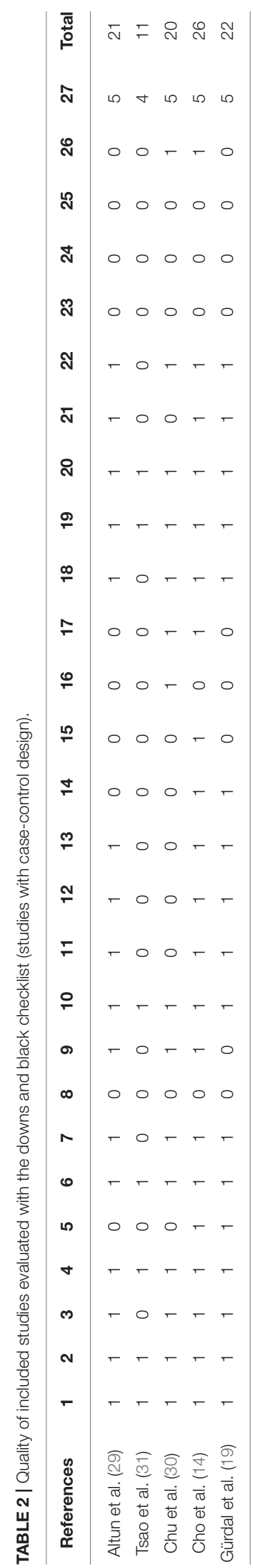


TABLE 3 | Quality of included studies assessed by the JBI critical appraisal checklist (cross sectional studies).

\begin{tabular}{|c|c|c|c|}
\hline \multirow[t]{2}{*}{ Criteria } & \multicolumn{3}{|c|}{ References } \\
\hline & Tsao et al. (13) & Akil et al. (28) & $\begin{array}{l}\text { Cosansu and } \\
\text { Yilmaz (32) }\end{array}$ \\
\hline 1. Were the criteria for inclusion in the sample clearly defined? & Yes & Yes & Yes \\
\hline 2. Were the study subjects and the setting described in detail? & Yes & Yes & Yes \\
\hline 3. Was the exposure measured in a valid and reliable way? & Yes & Yes & Yes \\
\hline 4. Were objective, standard criteria used for measurement of the condition? & Yes & Yes & Yes \\
\hline 5. Were confounding factors identified? & Yes & Yes & Yes \\
\hline 6. Were strategies to deal with confounding factors stated? & Yes & Yes & Yes \\
\hline 7. Were the outcomes measured in a valid and reliable way? & Yes & Yes & Yes \\
\hline 8. Was appropriate statistical analysis used? & Yes & Yes & Yes \\
\hline
\end{tabular}

thickness of epicardial fat, they had a greater number of risk factors and their associated stroke.

The included studies established an association with older age and BMI with the thickness of the EAT. The relationship between BMI and EAT was also observed by Iacobellis et al. (33), where individuals with metabolic syndrome (MetS) with a waist ratio of $104 \mathrm{~cm}$ in men and $98 \mathrm{~cm}$ in women had significantly higher values of EAT ( $9.5 \mathrm{~mm} \pm 7-20$ in men) and $4.5 \mathrm{~mm} \pm 3-5.5$ in women when compared to individuals without MetS $(92 \mathrm{~cm}$ in men and $82 \mathrm{~cm}$ in women) with an EAT of $7.5 \mathrm{~mm} \pm 6-15$ in men and $3.5 \mathrm{~mm} \pm 2-4.5$ in women $-p<0.001$.

In addition to obesity, another possible link between stroke and increased EAT is inflammation. Mean of neutrophil/lymphocyte ratio (NLR) was significantly greater among ischemic stroke patients in relation to the control group ( $2.5 \pm .6$ vs. $1.8 \pm 0.4, P<0.001)$. (28).

Altun et al. (29) demonstrated in their findings that individuals who suffered a stroke event had less aortic distensibility compared to the control group, corroborating these findings, Dogan et al. (34) observed that in patients with newly diagnosed hypertension, the increase in EAT was significantly related to impaired aortic elastic properties.

The study by Tsao et al. (31) evaluated the volume of EAT around the left atrium and its association with the risk of stroke in patients with atrial fibrillation (AF). case group (stroke $+\mathrm{AF}$ ) than in the control group (without AF and without stroke). In this study, it can be seen that the accumulation of EAT in the left atrium is directly related to patients who suffered stroke and who had atrial fibrillation. This fact corroborates the evidence published by Batal et al. (35), who reported that greater thickness of the posterior left atrium is associated with AF. It was also demonstrated by Tsao et al. (36) in a sample of patients with $\mathrm{AF}$ and control patients that the EAT was significantly increased in patients with $\mathrm{AF}$ and was associated with a higher incidence of AF recurrence after catheter ablation. In addition, a metaanalysis carried out also showed an increase in EAT in patients with AF (37).

Chu et al. (30) demonstrated that higher volumes of EAT are associated with future risks of cardiovascular disease (including stroke) in patients with atrial fibrillation in an elderly population (mean of 70 years), and it was independent association between age and EAT was observed. Other studies $(8,32,38)$ also observed this finding and showed that the volume of the EAT tends to increase with age, and the study by Abbara et al. (39) points out that the EAT is thicker in people over 65 years old. In addition, the population studied by Chu et al. (30) presented overweight BMI in both groups, enhancing what detailed studies previously showed that overweight may be influencing the thickness of epicardial fat.

Cho et al. (14) conducted a retrospective cohort to assess the thickness of the EAT and the levels of free fatty acids as predictors of acute ischemic stroke in patients with AF. The analysis of the EAT was performed by means of echocardiography, which showed by means of multivariate logistic regression, the study demonstrated that age and EAT are independently associated with ischemic stroke.

Mahabadi et al. (40) included a total of 1,267 participants who underwent computed tomography to quantify the volumes of EAT, intrathoracic fat and visceral abdominal adipose tissue. In this study it was shown that EAT was significantly associated with coronary artery disease and acute myocardial infarction, however, only visceral abdominal adipose tissue was associated with stroke. The lack of association between EAT and stroke in this study can be explained by the small number of cerebrovascular events that the studied population had (in comparison with other cardiovascular diseases, such as acute myocardial infarction).

Taguchi et al. (41) observed a significant association between the volume of EAT and the prevalence of coronary artery disease in their sample of Japanese men. Cosansu and Yilmaz (32) observed in their study that EFT can be an independent predictor for the development of acute ischemic stroke in patients with AF.

We must consider the possible role of epicardial fat thickness in strokes of unknown cause (cryptogenic strokes, also including ESUS). The association between different types of pathogenic strokes and the thickness of epicardial fat may be related to the presence of atrial heart disease, which is currently considered one of the possible hidden causes of this type of stroke. In this view, multiple factors (such as inflammation, thickness of epicardial fat, changes in the autonomic nervous system) may be linked to 
atrial changes that favor the cardioembolic mechanisms in these strokes (41-45).

\section{STRENGTHS AND LIMITATION OF THE STUDY}

Firstly, we observed that there are some differences regarding the EAT cut-off points established among authors or even the lack of it in some studies. Second, a meta-analysis could not be carried out showing significant difference in study designs and missing information in group was also a factor of decreased the quality of the studies. We can also highlight a moderate heterogeneity between studies, and different imaging modalities such as echocardiography measuring thickness and $\mathrm{mm}$, and CT and MRI measuring epicardial fat diameter, the small number of participants in some studies and the lack of control group was also a factor of decreased the quality of the studies. A TOAST classification denotes five subtypes of ischemic stroke: (1) atherosclerosis of large arteries, (2) cardioembolism, (3) occlusion of small vessels, (4) stroke of another given etiology and (5) stroke of undetermined etiology. Unfortunately, this classification hás not been obtained in several studies. In most studies, EFT was considered a risk factor for stroke and in only one cross-sectional study as a predictor of stroke. These data should be corroborated in large outlined studies and with a longer follow-up time. In this first systematic review to analyze the association between EAT and stroke, it was seen that the greater thickness of the EAT was more prevalent in all stroke groups than in groups without stroke. In summary of the data found, five studies used echocardiography to measure the thickness of epicardial fat and three performed CT and/or MRI to assess its volume. Patients with higher BMI, waist circumference, were older, obese, embolic stroke (ESUS), stroke and AF, respectively,

\section{REFERENCES}

1. Bertaso AG, Bertol D, Duncan BB, Foppa M. Epicardial fat: definition, measurements and systematic review of main outcomes [in Portuguese]. Arq Bras Cardiol. (2013) 101:18-28. doi: 10.5935/abc.20130138

2. Iacobellis G, Willens HJ. Echocardiographic epicardial fat: a review of research and clinical applications. J Am SocEchocardiogr. (2009) 22:1311-9. doi: 10.1016/j.echo.2009.10.013

3. Ouwens DM, Sell H, Greulich S, Eckel J. The role of epicardial and perivascular adipose tissue in the pathophysiology of cardiovascular disease. $J$ Cell Mol Med. (2010) 14:2223-34. doi: 10.1111/j.1582-4934.2010.01141.x

4. Schäffler A, Schölmerich J. Innate immunity and adipose tissue biology. Trends Immunol.2010 31:228-35. doi: 10.1016/j.it.2010.03.001

5. Iacobellis G, RibaudoMC, Assael F, Vecci E, Tiberti C, Zappaterreno A, et al. Echocardiographic epicardial adipose tissue is related to anthropometric and clinical parameters of metabolic syndrome: a new indicator of cardiovascular risk. J ClinEndocrinolMetab. (2003) 88:5163-8. doi: 10.1210/jc.2003-030698

6. Machann J, Thamer C, Schnoedt B, Haap M, Haring HU, Claussen CD, et al. Standardized assessment of whole body adipose tissue topography by MRI. $J$ MagnReson Imaging. (2005) 21:455-62. doi: 10.1002/jmri.20292

7. Mahabadi AA, Massaro JM, Rosito GA, Levy D, Murabito JM, Wolf PA, et al. Association of pericardial fat, intrathoracic fat, and visceral abdominal fat with cardiovascular disease burden: the Framingham Heart Study. Eur Heart J. (2009) 30:850-6. doi: 10.1093/eurheartj/ehn573 had higher levels of epicardial fat. In the assessment of epicardial fat thickness, a greater association was observed with the NTproBNP biomarkers and when it was evaluated by volume, an association was found with the increase in FFA levels (46-53).

\section{CONCLUSION}

Despite not being able to establish an association between EAT and stroke, we have organized and assessed all the research papers on this topic, highlighting their limitations, suggesting targets for future research and pointing out gaps in the literature.

\section{DATA AVAILABILITY STATEMENT}

The raw data supporting the conclusions of this article will be made available by the authors, without undue reservation.

\section{AUTHOR CONTRIBUTIONS}

LR, ED, GB-Z, and LDL conceived the study idea and planned the study methodology. LR, GB-Z, TL, GT, OP-N, AD, MN, MS, ER, and $\mathrm{AH}$ participated in the design and coordination of the study. LR was primarily responsible for protocol writing and developed the search strategy. AG and MR screened the studies, conduct data extraction and analysed the review findings. All authors read the drafts, provided comments and agreed on the final version of the manuscript.

\section{ACKNOWLEDGMENTS}

MR and AG thanks the National Council for Scientific and Technological Development (CNPq). MR and AG receive from $\mathrm{CNPq}$ (Brazil) productivity fellowships.
8. Alexopoulos N, McLean DS, Janik M, Arepalli CD, Stillman AE, Raggi P. Epicardial adipose tissue and coronary artery plaque characteristics. Atherosclerosis. (2010) 210:150-4. doi: 10.1016/j.atherosclerosis.2009. 11.020

9. Ferris WF, Crowther NJ. Once fat was fat and that was that: our changing perspectives on adipose tissue. Cardiovasc J Afr. (2011) 22:147-54. doi: 10.5830/CVJA-2010-083

10. Karadag B, Ozulu B, Ozturk FY, Oztekin E, Sener N, Altuntas Y. Comparison of epicardial adipose tissue (EAT) thickness and anthropometric measurements in metabolic syndrome (MS) cases above and under the age of 65. Arch GerontolGeriatr. (2011) 52:79-84. doi: 10.1016/j.archger.2010. 06.016

11. Rabkin SW. The relationship between epicardial fat and indices of obesity and the metabolic syndrome: a systematic review and meta-analysis. MetabSyndrRelat Disord. (2014) 12:31-42. doi: 10.1089/met.2013.0107

12. Roever L, Resende ES, Diniz AL. Abdominal obesity and association with atherosclerosis risk factors. Medicine. (2016) 95:e1357. doi: 10.1097/MD.0000000000001357

13. Tsao HM, Hu WC, Tsai PH, Lee CL, Liu FC, Wang HH, et al. The abundance of epicardial adipose tissue surrounding left atrium is associated with the occurrence of stroke in patients with atrial fibrillation. Medicine. (2016) 95:e3260. doi: 10.1097/MD.0000000000003260

14. Cho KI, Kim BJ, Cho SH, Lee JH, Kim MK, Yoo BG. Epicardial fat thickness and free fatty acid level are predictors of acute ischemic 
stroke with atrial fibrillation. J Cardiovasc Imaging. (2018) 26:65-74. doi: 10.4250/jcvi.2018.26.e1

15. GBD 2016 Stroke Collaborators. Global, regional, and national burden of stroke, 1990-2016: a systematic analysis for the Global Burden of Disease Study 2016. Lancet Neurol. (2019) 18:439-58. doi: 10.1016/S1474-4422(19)30034-1

16. Avezum Á, Costa-Filho FF, Pieri A, Martins SO, Marin-Neto JA. Stroke in Latin America: burden of disease and opportunities for prevention. Glob Heart. (2015) 10:323-31. doi: 10.1016/j.gheart.2014.01.006

17. Guyatt GH, Oxman AD, Vist GE, Kunz R, Falck-Ytter Y, AlonsoCoello P, et al. GRADE: an emerging consensus on rating quality of evidence and strength of recommendations. BMJ. (2008) 336:924-6. doi: 10.1136/bmj.39489.470347.AD

18. World Health Organization. World Health Statistics 2018: Monitoring Health for the SDGs, Sustainable Development Goals. Geneva: World Health Organization (2018). Available online at: https://apps.who.int/iris/bitstream/ handle/10665/272596/9789241565585-eng.pdf (accessed January, 2021).

19. Gürdal A, Keskin K, Orken DN, Baran G, Kiliçkesmez K. Evaluation of epicardial fat thickness in young patients with embolic stroke of undetermined source. Neurologist. (2018) 23:113-7. doi: 10.1097/NRL.0000000000000182

20. Roger VL, Go AS, Lloyd-Jones DM, Benjamin EJ, Berry JD, Borden WB, et al. Heart disease and stroke statistics-2012 update: a report from the American Heart Association. Circulation. (2012) 125:e2220. doi: 10.1161/CIR.0b013e31823ac046

21. GBD 2016 Neurology Collaborators. Global, regional, and national burden of neurological disorders, 1990-2016: a systematic analysis for the Global Burden of Disease Study 2016. Lancet Neurol. (2019) 18:459-80. doi: 10.1016/S1474-4422(18)30499-X

22. Lackland DT, Roccella EJ, Deutsch AF, Fornage M, George MG, Howard G, et al. Factors influencing the decline in stroke mortality: a statement from the American Heart Association/American Stroke Association. Stroke. (2014) 45:315-53. doi: 10.1161/01.str.0000437068.30550.cf

23. Bensenor IM, Goulart AC, Szwarcwald CL, Vieira ML, Malta DC, Lotufo PA. Prevalence of stroke and associated disability in Brazil: National Health Survey-2013. ArqNeuropsiquiatr. (2015) 73:746-50. doi: 10.1590/0004-282X20150115

24. Liberati A, Altman DG, Tetzlaff J, Altman DG, PRISMA Group. Preferred reporting items for systematic reviews and meta-analyses: the PRISMA statement. BMJ. (2009) 21 339:b700. doi: 10.1136/bmj.b2700

25. Richardson WS, Wilson MC, Nishikawa J, Hayward RS. The well-built clinical question: akey to evidence-based decisions. ACP J Club. (1995) 123:A12-3.

26. Downs S, e Black N. The feasibility of creating a checklist for the assessment of the methodological quality both of randomized and nonrandomized studies of health care interventions. J Epidemiol Community Health. (1998) 52:377-84. doi: 10.1136/jech.52.6.377

27. Joanna Briggs Institute. Checklist for Analytical Cross Sectional Studies. Available online at: www.joannabriggs.org (accessed December 18, 2020).

28. Akil E, Akil MA, Varol S, Özdemir HH, Yücel Y, Arslan D, et al. Echocardiographic epicardial fat thickness and neutrophil to lymphocyte ratio are novel inflammatory predictors of cerebral ischemic stroke. J Stroke Cerebrovasc Dis. (2014) 23:2328-34. doi: 10.1016/j.jstrokecerebrovasdis.2014.04.028

29. Altun I, Unal Y, Basaran O, Akin F, Emir GK, Kutlu G, et al. Increased epicardial fat thickness correlates with aortic stiffness and n-terminal probrain natriuretic peptide levels in acute ischemic stroke patients. Tex Heart Inst J. (2016) 43:220-6. doi: 10.14503/THIJ-15-5428

30. Chu CY, Lee WH, Hsu PC, Lee MK, Lee HH, Chiu C, et al. Association of increased epicardial adipose tissue thickness with adverse cardiovascular outcomes in patients with atrial fibrillation. Medicine. (2016) 95:e2874. doi: 10.1097/MD.0000000000002874

31. Tsao HM, Hu WC, Chen SA. Epicardial fat and circulatory stasis of the left atrium appendage are associated with the embolic stroke in patients with atrial fibrillation. Imaging. (2013) 34:975. doi: 10.1093/eurheartj/eht310. P5355

32. Cosansu K, Yilmaz S. Is epicardial fat thickness associated with acute ischemic stroke in patients with atrial fibrillation? J StrokeCerebrovascDis. (2020) 29:104900. doi: 10.1016/j.jstrokecerebrovasdis.2020.104900
33. Iacobellis G, Willens HJ, Barbaro G, Sharma AM. Threshold values of highrisk echocardiographic epicardial fat thickness. Obesity. (2008) 16:887-92. doi: $10.1038 /$ oby.2008.6

34. Dogan M, Turak O, Akyel A, Grboviç E, Mendi MA, Oksüz F, et al. Increased epicardial adipose tissue thickness is linkedto aortic stiffness in patients with primary hypertension. Blood Press. (2014) 23:222-7. doi: 10.3109/08037051.2013.863991

35. Batal O, Schoenhagen $P$, Shao M, Ayyad AE, Van Wagoner DR, Halliburton SS, et al. Left atrial epicardial adiposity and atrial fibrillation. CircArrhythmElectrophysiol. (2010) 3:230-6. doi: 10.1161/CIRCEP.110.957241

36. Tsao HM, Hu WC, Wu MH, Tai CT, Lin YJ, Chang SL, et al. Quantitative analysis of quantity and distribution of epicardial adipose tissue surrounding the left atrium in patients with atrial fibrillation and effect of recurrence after ablation. Am J Cardiol. (2011) 107:498-503. doi: 10.1016/j.amjcard.2011.01.027

37. Hatem SN, Sanders P. Epicardial adipose tissue and atrial fibrillation. Cardiovasc Res. (2014) 102:205-13. doi: 10.1093/cvr/cvu045

38. Shmilovich H, Dey D, Cheng VY, Rajani R, Nakazato R, Otaki Y, et al. Threshold for the upper normal limit of indexed epicardial fat volume: derivation in a healthy population and validation in an outcome-based study. Am J Cardiol. (2011) 108:1680-5. doi: 10.1016/j.amjcard.2011.07.031

39. Abbara S, Desai JC, Cury RC, Butler J, Nieman K, Reddy V. Mapping epicardial fat with multi-detector computed tomography to facilitate percutaneous transepicardial arrhythmia ablation. Eur J Radiol. (2006) 57:417-22. doi: 10.1016/j.ejrad.2005.12.030

40. Mahabadi AA, Berg MH, Lehmann N, Kälsch H, Bauer M, Kara K, et al. Association of epicardial fat with cardiovascular risk factors and incident myocardial infarction in the general population: the Heinz Nixdorf Recall Study. J Am CollCardiol. (2013) 61:1388-95. doi: 10.1016/j.jacc.2012.11.062

41. Taguchi R, Takasu J, Itani Y, Yamamoto R, Yokoyama K, Watanabe S, et al. Pericardial fat accumulation in men as a risk factor for coronary artery disease. Atherosclerosis. (2001) 157:203-9. doi: 10.1016/S0021-9150(00)00709-7

42. Acampa M, Lazzerini PE, Martini G. Atrial cardiopathy and sympathovagal imbalance in cryptogenicstroke: pathogenic mechanisms and effects on electrocardiographic markers. Front Neurol. (2018) 9:469. doi: 10.3389/fneur.2018.00469

43. Wilding JPH, Jacob S. Cardiovascular out come trials in obesity: a review. ObesityReviews. (2021) 22:e13112. doi: 10.1111/obr.13112

44. Saco-Ledo G, Valenzuela PL, CastilloGarcía A, Arenas J, LeónSanz M, Ruilope LM, et al. Physical exercise and epicardial adipose tissue: a systematic review and meta-analysis of randomized controlled trials. Obes Rev. (2020) 22:1-11. doi: 10.1111/obr.1 3103

45. Launbo N, Zobel EH, von Scholten BJ, Færch K, Jørgensen PG, Christensen RH. Targeting epicardial adipose tissue with exercise, diet, bariatric surgery or pharmaceutical interventions: a systematic review and meta analysis. Obes Rev. (2020) 22:1-16. doi: 10.1111/obr.13136

46. Higgins JP, Thompson SG, Deeks JJ, Altman DG. Measuring inconsistency in meta-analyses. BMJ. (2003) 327:557-60. doi: 10.1136/bmj.327.7414.557

47. DerSimonian R, Laird N. Meta-analysis in clinical trials. Control Clin Trials. (1986) 7:177-88. doi: 10.1016/0197-2456(86)90046-2

48. Higgins JP, Thompson SG. Quantifying heterogeneity in a meta-analysis. Stat Med. (2002) 21:1539. doi: 10.1002/sim.1186

49. Review Manager (RevMan) [Computer program]. Version 5.3. Copenhagen: The Nordic Cochrane Centre, The Cochrane Collaboration (2014).

50. Gaeta M, Bandera F, Tassinari F, Capasso L, Cargnelutti M, Pelissero G, et al. Isepicardialfatdepotassociatedwithatrialfibrillation? A systematicreviewand meta-analysis. Europace. (2017) 19:747-52. doi: 10.1093/europace/euw398

51. Fox CS, Gona P, Hoffmann U, Porter SA, Salton CJ, Massaro $J M$, et al. Pericardial fat, intrathoracic fat, and measures of left ventricular structure and function: the Framingham heart study. Circulation. (2009) 119:1586-91. doi: 10.1161/CIRCULATIONAHA.108.82 8970

52. Silaghi A, Piercecchi-Marti M-D, Grino M, Leonetti G, Alessi MC, Clement $\mathrm{K}$, et al. Epicardial adipose tissue extent: relationship with age, body fat distribution, and coronaropathy. Obesity. (2008) 16:2424-30. doi: $10.1038 /$ oby.2008.379 
53. Rosito GA, Massaro JM, Hoffmann U, Ruberg FL, Mahabadi AA, Vasan RS, et al. Pericardial fat, visceral abdominal fat, cardiovascular disease risk factors, and vascular calcification in a community-based sample. Circulation. (2008) 117:605-13. doi: 10.1161/CIRCULATIONAHA.107.743062

Conflict of Interest: The authors declare that the research was conducted in the absence of any commercial or financial relationships that could be construed as a potential conflict of interest.
Copyright $\odot 2021$ Rosa, Grande, Lima, Dondossola, Uggioni, Hernandez, Tse, Liu Pontes-Neto, Biondi-Zoccai, Neto, Durães, Sá, Resende and Roever. This is an openaccess article distributed under the terms of the Creative Commons Attribution License (CC BY). The use, distribution or reproduction in other forums is permitted, provided the original author(s) and the copyright owner(s) are credited and that the original publication in this journal is cited, in accordance with accepted academic practice. No use, distribution or reproduction is permitted which does not comply with these terms. 